\title{
FISCAL INCIDENCE IN TANZANIA
}

Stephen D. Younger, Flora Myamba, and Kenneth Mdadila

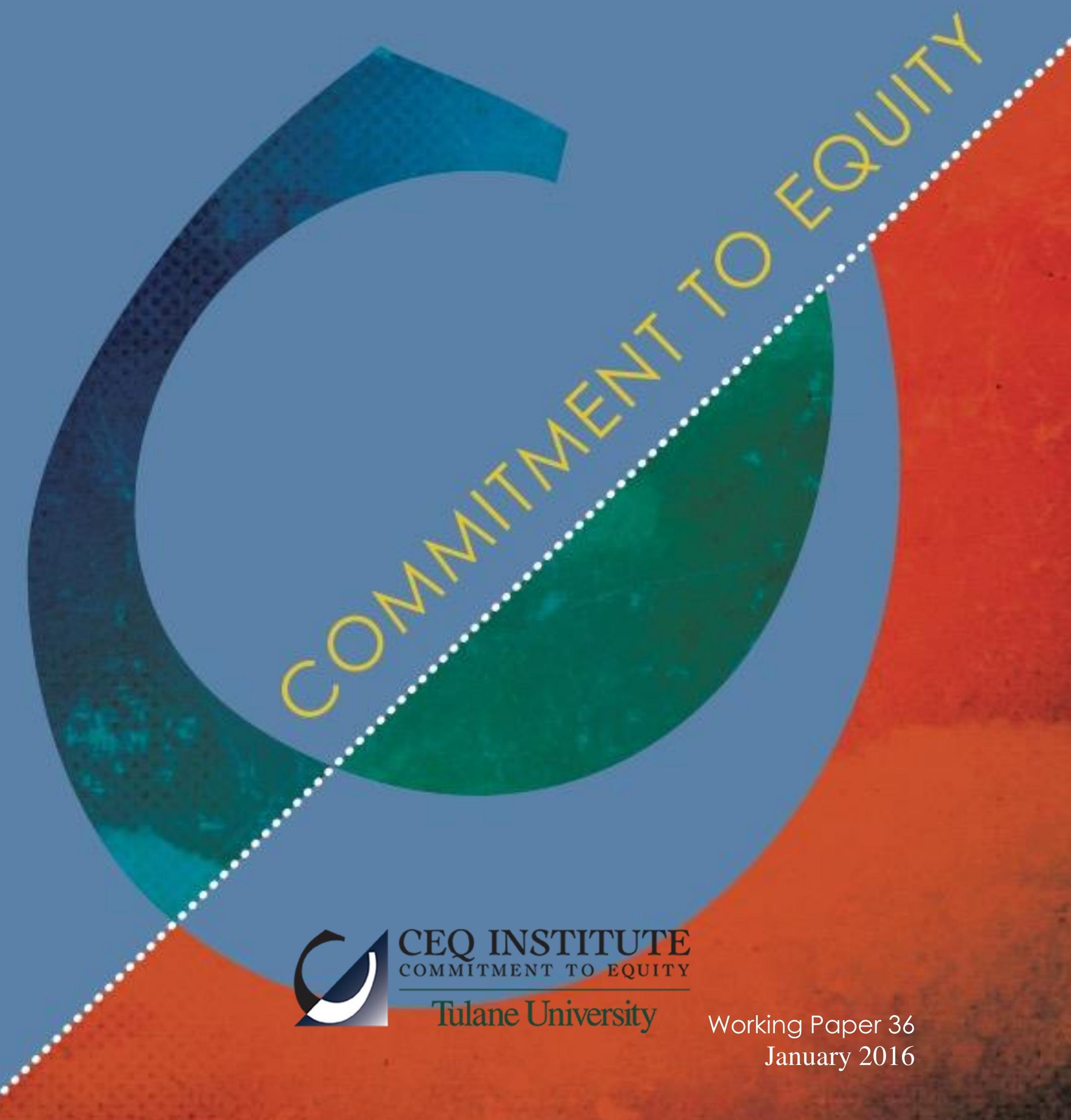




\section{The CEQ Working Paper Series}

The CEQ Institute at Tulane University works to reduce inequality and poverty through rigorous tax and benefit incidence analysis and active engagement with the policy community. The studies published in the CEQ Working Paper series are pre-publication versions of peer-reviewed or scholarly articles, book chapters, and reports produced by the Institute. The papers mainly include empirical studies based on the CEQ methodology and theoretical analysis of the impact of fiscal policy on poverty and inequality. The content of the papers published in this series is entirely the responsibility of the author or authors. Although all the results of empirical studies are reviewed according to the protocol of quality control established by the CEQ Institute, the papers are not subject to a formal arbitration process. The CEQ Working Paper series is possible thanks to the generous support of the Bill \& Melinda Gates Foundation. For more information, visit www.commitmentoequity.org.

The CEQ logo is a stylized graphical representation of a Lorenz curve for a fairly unequal distribution of income (the bottom part of the $\mathrm{C}$, below the diagonal) and a concentration curve for a very progressive

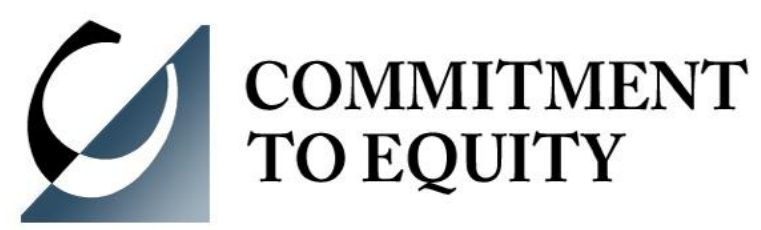
transfer (the top part of the C). 


\title{
FISCAL INCIDENCE IN TANZANIA*
}

\author{
Stephen D. Younger, Flora Myamba and Kenneth Mdadila ${ }^{\dagger}$ \\ CEQ Working Paper 36
}

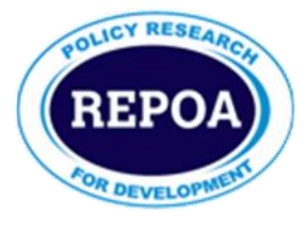

JANUARY 2016

ABSTRACT

We use methods developed by the Commitment to Equity and data from the 2011/12 Household Budget Survey to assess the effects of government taxation, social spending, and indirect subsidies on poverty and inequality in Tanzania. We also simulate several policy reforms to assess their distributional consequences. We find that Tanzania redistributes more than expected given its relatively low income and inequality, largely because both direct and indirect taxes are more progressive than in other countries. Tanzania's nascent conditional cash transfer program has an excellent targeting mechanism. If the program were expanded to a size that is typical for lower-middle income countries, it could reduce poverty significantly. On the other hand, electricity subsidies are regressive despite attempts to make them more pro-poor with a lifeline tariff.

Keywords: fiscal incidence, poverty, inequality, fiscal policy, Tanzania

JEL: D31, H22, I14

\footnotetext{
* The CEQ Assessment Tanzania has been produced by the Commitment to Equity Institute. The study was possible thanks to the generous support from the Bill \& Melinda Gates Foundation. Launched in 2008, the CEQ project is an initiative of the Center for Inter-American Policy and Research (CIPR) and the Department of Economics, Tulane University, the Center for Global Development and the Inter-American Dialogue. The CEQ project is housed in the Commitment to Equity Institute at Tulane. For more details, visit www.commitmentoequity.org.

t Stephen D. Younger is Scholar in Residence in the Department of Economics, Ithaca College. Flora Myamba is Senior Researcher in Social Protection, REPOA. Kenneth Mdadila is a Lecturer in the Department of Economics, University of Dar es Salaam. We are grateful to the following people who helped us understand taxation and social expenditure in Tanzania: Ussi Hussein, Timothy Ibianga, Cypria Iraba, Irene Isaka, George Kabelwa, Ali Khalifa, Evagenline Kizwalo, Bernard Konga, Decklan P. Mhaiki, Gregory L.E. Millinga, Richard Mkumbo, Abassy Mlemba, Gerard Mueli, Tonedeus K. Muganyizi, Emmanuel Mungunasi, Felix M. Ngamloagosi, Christopher M.T. Sanga, Shaban Seleman, Valerian Tesha, Erastrum Tutuba, Charles W. Wamanyi, John Wearing, and David Wiswaro. In addition, we thank Nora Lustig and her colleagues at the Commitment to Equity Institute, particularly Samantha Greenspun, Ali Enami, Sean Higgins, and Sandra Martinez for many useful discussions on methods and interpretation of the results. Any remaining errors are our own.
} 


\section{INTRODUCTION}

One of the functions of government is to redistribute resources, especially to the most disadvantaged members of society. While there is considerable disagreement over both the extent and the means to effect such redistribution, most people agree that society is better off if inequality and poverty can be reduced, and all governments do, in fact, redistribute income with their tax and expenditure policies, though not always progressively. The purpose of this paper is to examine the extent to which the government of Tanzania does so. In particular, the paper addresses three general questions:

- How much redistribution and income poverty reduction is being accomplished through social spending, subsidies and taxes?

- How progressive are revenue collection, subsidies, and government social spending? and

- Within the limits of fiscal prudence, what could be done to increase redistribution and poverty reduction through changes in taxation and spending?

Such information is useful for policy makers in two broad ways. First, the government of Tanzania commits itself to reducing poverty and inequality and increasingly adopts policies explicitly intended to alter the distribution of income. Examples include: MKUKUTA, a national level strategy aimed at reducing poverty and inequality through improved access to health, education, water and sanitation services; a Productive Social Safety Net Program which includes a conditional cash transfer program; free food provided under the National Strategic Reserve Fund (NSRF); free school books and uniforms for some disadvantaged children; and distribution of free bed nets. This study will give information on the effectiveness of these and other policies at redistributing income and also evaluate the distributional consequences of several proposed policy changes.

Second, the study will give an estimate of the overall effect of government spending and taxation the "fisc" - on the distribution of income and compare Tanzania's performance to other African countries.

Every incidence analysis should include a preemptory caution. When we find that one tax or expenditure is more redistributive to the poor than another, the temptation is to conclude that the former is preferable. But it is important to remember that redistribution is only one of many criteria that matter when making public policy. In particular, efficiency matters too, so not all redistributive taxes or expenditures are good ones, and not all good taxes or expenditures are redistributive. The results of this study and of all incidence studies are one input to public policy making, one which should be weighed with other goals before deciding that a tax or expenditure is desirable. 


\section{METHODS AND APPROACH}

The paper uses incidence analysis, a description of who benefits when the government spends money and who loses when the government taxes, following the methods developed by the Commitment to Equity (CEQ) Institute ${ }^{1}$ (Lustig, forthcoming). While it is possible to use incidence analysis to examine one particular expenditure or tax, the thrust of the CEQ analysis is rather to get a comprehensive picture of the redistributive effect of as many tax and expenditure items as possible. This is accomplished by comparing five core income concepts and eight complementary ones. Figure 1 shows the relationship between these income measures and helps to illustrate how we use them to analyze the distributional effects of fiscal policy.

Market income is income before the government has any influence on the income distribution with its tax and spending policies. It includes all earned and unearned income except government transfers and contributory pension receipts. There is some debate as to whether pensions should be considered as deferred compensation for previous employment, and thus earned income, or a transfer payment. ${ }^{2}$ For Tanzania, where almost all retirement benefits are contributory and all but one of the various pension funds seem reasonably well-funded, it is best to view pensions as deferred compensation. The World Bank projects asset depletion points far in the future for all pension funds except the Public Service Pension Fund (PSPF). But as the name implies, that fund applies only to public sector employees, so even if it eventually requires budget support from central government, that should still be viewed as deferred compensation from the employer (government) rather than a subsidy to that particular pension fund. For these reasons, "market income plus pensions" is best viewed as the "pre-fisc" income concept for Tanzania.

\footnotetext{
${ }^{1}$ Launched in 2008, the CEQ project is an initiative of the Center for Inter-American Policy and Research (CIPR) and the Department of Economics, Tulane University, the Center for Global Development and the Inter-American Dialogue. The CEQ project is housed in the Commitment to Equity Institute at Tulane. For more details visit www.commitmentoequity.org.

2 Discussion of this issue can be found in Breceda et al., 2008; Immervoll et al., 2009, Goñi et al., 2011; Lindert et al., 2006; and Silveira et al., 2011.
} 


\section{FIGURE 1 - DEFINITION OF CEQ INCOME CONCEPTS}

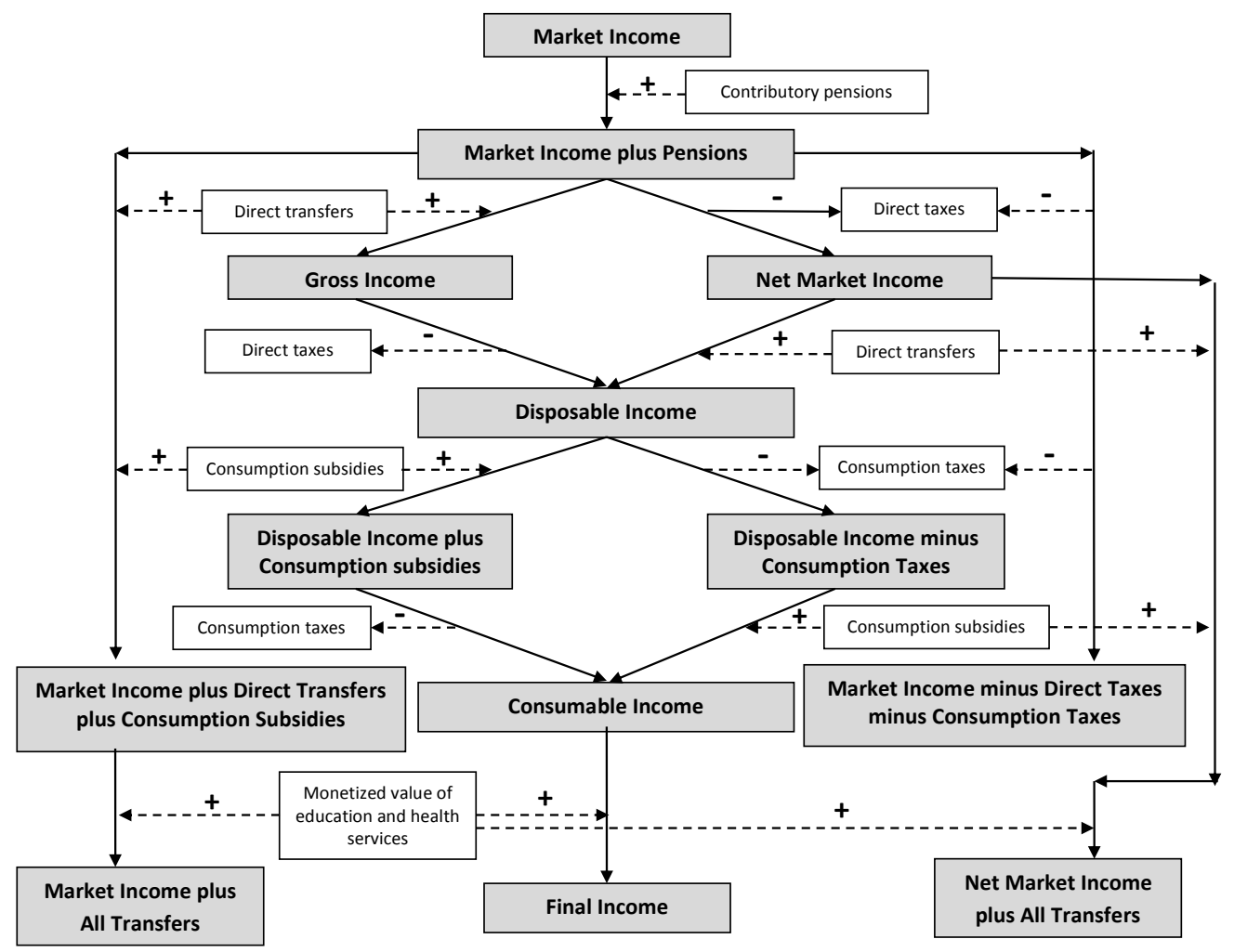

Source: Lustig and Higgins, forthcoming

Disposable income is cash income available after government has taken away direct taxes such as personal income tax (PAYE) and has distributed direct transfers such as conditional cash transfers as well as "near cash" transfers such as free school books and uniforms or bed nets. Because direct taxes and direct transfers often have very different distributional consequences, it is sometimes helpful to consider their influence separately, thus the two intermediate income concepts between market and disposable income in Figure 1. Gross income is market income plus direct transfers; net market income is market income less direct taxes.

While that is the end of government's impact on nominal cash income, many government policies affect households' real income indirectly by altering the prices that they pay. Consumable income is disposable income less indirect taxes - VAT, import duties, and excise taxes - plus indirect subsidies, such as the support that government gives to electricity generators and distributors. Again, there are two intermediate income concepts between disposable and consumable income to capture the effect of indirect taxes and subsidies separately.

The last way that government influences the income distribution is through the provision of free or subsidized services such as health and education. Final income is consumable income plus the value of these in-kind benefits, less any user fees paid for those services. Moving from consumable to final income highlights the effect on poverty and inequality of public health and education expenditures. Our assumptions on the economic incidence of taxes are simple: direct taxes are born entirely by the income earner; indirect taxes are born entirely by the consumer. This latter assumption is not 
Younger, Myamba and Mdadila, WP 36, January 2016

entirely appropriate if markets are not competitive, and many are not in Tanzania. However, the extent to which monopolies or oligopolies shift indirect taxes to consumers is not clear, and could be either greater or less than 100\% depending on the functional form of the demand function (Fullerton and Metcalf, 1992). Since we have no information on those functional forms, we assume that $100 \%$ of taxes are shifted to consumers regardless of market structure.

The one exception we have made to these simple incidence assumptions is the fertilizer subsidy, which we assume falls on the food producers that receive it, not food consumers.

\section{DATA}

To understand the distributional consequences of taxes and public expenditures, we need data on all of the above income concepts for a representative sample of individuals in the country. We can then use those data to construct income distributions for each income concept outlined in the previous section and derive summary statistics for those distributions. In Tanzania, we use the 2011/12 Household Budget Survey (HBS), the most recent such survey in the country. ${ }^{3}$ In addition, we use administrative tax and expenditure data from fiscal 2011/12 to estimate some of the information needed, most specifically the per-beneficiary amount of spending on public education and health services.

\section{i. Construction of the Income and Expenditure Variables}

\section{Disposable Income}

Our construction of the CEQ income concepts starts with disposable income and works backward to market incomes and forward to final incomes. (See Figure1). We assume that the welfare measure most commonly used from the HBS, household expenditures, is closest conceptually to disposable income. We use the expenditure variable as constructed by the National Bureau of Statistics though, as will become evident, we usually divide it by household size rather than an adult equivalence scale to measure "welfare." This is to keep our results as comparable as possible to CEQ studies in other countries. $^{4}$

\section{Market Income plus Pensions}

We construct market income as disposable income plus all direct taxes and less all direct transfers. Gross income and net market income follow in the obvious fashion.

Tanzania's only cash transfer program, the conditional cash transfer, was still in a pilot phase in 2011/12 at the time of the HBS, so the survey includes only a very small number of beneficiaries which is unlikely to be representative of actual beneficiaries. For that reason, we have not included it

\footnotetext{
${ }^{3}$ http://www.nbs.go.tz/tnada/index.php/catalog/36/study-description

${ }^{4}$ Similar studies can be found at http://www.commitmentoequity.org.
} 
in the incomes that we construct here. ${ }^{5}$ Nevertheless, later in the study we will simulate beneficiaries based on the selection criteria for the CCT in order to discuss its incidence and the effects on poverty and inequality of scaling up the CCT program to a larger budget and more beneficiaries.

Tanzania also has a few quasi-cash transfers: provision of free or subsidized goods. These include school books and uniforms, bed nets, and food (mostly maize) provided under the NSRF. The HBS asks households about assistance they have received with these items, but it does not ask about the source of this assistance, which could be government, NGOs, or family members. For uniforms, books, and bed nets, the overall amounts reported are small and because we have no means of judging how important government provision is relative to the other sources, we have assumed that all reported transfers are from government and thus included them in the analysis. Responses to questions about assistance with "food" are much larger, and it is easy to imagine that households receive such assistance from sources other than the National Food Reserve Agency (NFRA). To account for this, we first removed households reporting receipt of amounts that were too large, small, or frequent to be consistent with NFRA's delivery of 400 grams of grain per person per day. We then scaled each household's reported assistance received by the ratio of the total grain that NFRA reports having distributed in each region of the country during the HBS sampling period divided by the total grain households report having received. In all of these cases, our analysis will mix the incidence of publicly provided transfers with those from other sources, but that is unavoidable.

The same section of the HBS asks about pensions received, but only as an option under "other income." Not surprisingly, this greatly under-reports pension income. Instead of using this information, we calculated the total pensions received in the second wave of the National Panel Survey (collected in 2012/13) by each percentile of the expenditure per capita distribution in that survey and then assigned that amount to the members of each percentile of the expenditure per capita distribution in the HBS, dividing it equally among all members of the percentile.

For direct taxes, the HBS does not ask directly about employee income taxes paid (PAYE), so we must simulate these values. We assume that formal sector workers pay statutory rates for personal income tax (PIT), the skills development levy (SDL), and social security contributions (SSC). At the same time, there is widespread agreement that tax evasion through informality is an important problem in Tanzania, so we assume that the self-employed pay none of these taxes.

TABLE 1 - PERSONAL INCOME TAX RATES, TANZANIA, 2011/12

\begin{tabular}{|c|c|c|}
\hline & Chargeable & \\
\hline Income & Income & Rate \\
\hline Tranche & TZS per month & $\%$ \\
\hline First & 0 to 135,000 & 0.0 \\
\hline Second & 135,000 to 360,000 & 14.0 \\
\hline Third & 360,000 to 540,000 & 20.0 \\
\hline Fourth & 540,000 to 720,000 & 25.0 \\
\hline Fifth & 720,000 and up & 30.0 \\
\hline
\end{tabular}

${ }^{5}$ And even if we did, it would have a miniscule impact because there are so few beneficiaries in the survey. 
We define "formal" sector employees as those working for public sector or reporting that their job is "permanent and pensionable". Table 1 gives the statutory personal income tax (PAYE) rates that we apply to the earnings of formal sector workers. Social security contributions for these workers are a flat $20 \%$ of gross earnings and the Skills Development Levy is a flat $6 \%$.

The HBS questionnaire asks households who run their own non-farm businesses about their expenses, one of which is "taxes including trading fees \& licenses". We assume that these are presumptive taxes and count them as "direct" taxation, even though they are meant to capture both income tax and VAT. It is not possible to identify the owners of corporations, so we do not simulate the corporate income tax.

\section{Consumable Income}

To calculate consumable income, we return to our disposable income measure, add indirect subsidies, and subtract indirect taxes paid. There is only one important consumption subsidy in Tanzania, for electricity. To estimate this, we use a cost-of-provision study (AF Mercados, 2013) that is roughly concurrent with the HBS survey period. There are two possible tariff regimes for households, the lifeline tariff and the "general use" tariff. We assume that a $\mathrm{HH}$ chooses the structure that is most beneficial given its observed electricity consumption; it is almost always the lifeline. Then we back out its $\mathrm{kWh}$ consumption from reported expenditures on electricity and calculate the difference between what households paid per kWh and AF Mercados' estimate of a tariff that would cover the cost of provision.

There is also an input subsidy for fertilizer, the benefit of which we attribute to farmers, not consumers. (That is not consistent with other incidence assumptions in the analysis.) The HBS questionnaire does not ask whether a farmer received a subsidy, so we assume that all fertilizer purchases up to the maximum allowed under program rules receive the subsidy amount so long as the household produced either maize or rice, the targeted commodities.

Indirect taxes in Tanzania include import duties, VAT, and a variety of excises including on petroleum products, alcoholic beverages, soft drinks, bottled water, tobacco products, and communications services. Households do not pay these taxes explicitly, but they are reflected in the prices they pay for taxed goods and services. Estimating how much indirect tax a household has paid when purchasing a particular product is complicated by variable tax rates, significant tax evasion, and the fact that some of these taxes fall on intermediate products which then increase the prices of entirely different products. This latter problem is especially important for petroleum excises and import duties.

Unfortunately, Tanzania's most recent input-output table is based on very old data from the 1990s (despite an update in 2007, the basic structure is drawn from the earlier IO table) and our attempts to use it produced unreasonable results. So for VAT we applied the statutory rates on a product-byproduct basis for all the expenditures reported in the HBS, and then scaled the results down so that the national total we calculate from HBS is the same as the administrative total for both taxes. For VAT, this a scaling up by $96 \%$ while for import duties we scaled down by $84 \%$. This latter procedure accounts for underpayment and evasion, though it does so by assuming that all consumers' effective tax paid declines proportionally to their consumption. 
For petroleum duties and import duties, however, this approach is inadequate because so much of these products are consumed as intermediate goods. To deal with this in our analysis, we use the 2007 social accounting matrix (SAM) for Mozambique (IFPRI, 2014), a neighboring country with a similar economic structure, and a technique due to Roland-Holst and Sancho (1995) that calculates both the direct and indirect effects of petroleum excises on the final prices of all goods and services by tracing their impact through the input-output table. We then map the industries in the SAM to each item in the HBS expenditure modules, applying the "effective" (direct+indirect) tax rate from the SAM to the corresponding expenditure items. To account for differences in tax rates between Mozambique and Tanzania, we also scaled these taxes down by 4\% to match the total petroleum tax receipts in the administrative accounts.

For non-petroleum excises, on the other hand, we apply the statutory rates directly to households' consumption to estimate the implicit tax paid. This is because formal sector firms produce most of these products so the taxes are likely to be paid. Table 2 gives the excise rates in question.

\section{TABLE 2 - EXCISE DUTY RATES, TANZANIA, 2011/12}

\begin{tabular}{ll}
\hline Item & Rate \\
\hline Bottled water and soft drinks & 69 TZS per litre \\
Beer & 420 TZS per litre \\
Wine & 420 TZS per litre for domestic, 1345 for foreign \\
Spirits & $1993 \mathrm{TZS}$ per litre \\
Cigarettes & 6.83 TZS per cigarette for domestic brands, 16.10 for foreign \\
Gasoline & $339 \mathrm{TZS}$ per litre \\
Diesel /3 & $215 \mathrm{TZS}$ per litre \\
Kerosene /3 & $400.1 \mathrm{TZS}$ per litre \\
\hline Source: PWC (2011) &
\end{tabular}

\section{Final Income}

To calculate final income, we add in-kind transfers associated with public provision of education and health care to consumable income. This step is important because these items are a large share of social spending in Tanzania (see Table 5), and it is difficult because these services are often provided free-of-charge to recipients and, even when fees are charged, they do not reflect the government's full cost of provision. To estimate the value of these services to recipients, we calculate the government's total cost of provision for schooling by level (pre-primary, primary, secondary, tertiary, and vocational) and health care by type of service (in-patient vs. out-patient at public dispensaries, public health centers, and public hospitals). We then average that total cost by the number of beneficiaries and assume that each beneficiary receives that average amount of benefit less any fees that $\mathrm{s} /$ he paid for the service. This is the standard approach in benefit incidence studies (Demery, 2003), but it is perhaps better understood as "expenditure" incidence since it does not account for differences in the quality of services across different providers nor does it take into account differences in the value that recipients themselves place on these services. Table 3 gives our estimated value per beneficiary. For public schools, we use actual expenditures by level given in the 2013 World Bank Rapid Budget Assessment for education divided by the number of students reported in the 2012 Rapid Budget Assessment (World Bank, 2012, 2013). We have also applied the primary estimate to public pre-primary students as there is no independent estimate for them. There is no estimate of vocational students in the World Bank assessment, so we have divided that total 
costs in World Bank (2013) by an estimate of the number of vocational students from the HBS to get an average cost per vocational student. For health care, we have drawn estimates directly from the calculations in James, Bura, and Ensor (2013).

TABLE 3 - COST-OF-PROVISION FOR FREE AND SUBSIDIZED PUB LIC HEA
EDUCATION SERVICES

Notes: /1 For health care, cost per visit, not per year

\section{ii. Consistency between Administrative and Survey Data Sources}

It is possible to calculate the total amount that the government spends on certain items and taxes on others using both administrative data - the national accounts, the budget, etc. -- and data from the HBS survey. Because the HBS is a representative survey for mainland Tanzania, these amounts should coincide, but they sometimes do not. This can lead to errors in our estimate of distributional effects if the degree of inconsistency varies among the tax, expenditure, and income variables used in the analysis. For example, suppose that the total value of beer excises in the survey is half the amount found in the budget, perhaps because survey respondents are reluctant to report that they spend money on beer. If those excises are paid disproportionately by richer households, which seems likely, then their under-reporting in the survey will cause us to underestimate the impact that these taxes have on both inequality and poverty. It is important, then, to try to adjust for discrepancies between the administrative sources and the survey.

In Tanzania, apart from discrepancies and adjustments already noted, the largest discrepancies between the HBS estimates and the public accounts are for excise taxes on alcohol and tobacco. These items are grossly under-reported in the HBS, which means our estimate of the taxes paid on these items is also much lower than the actual revenues. Nevertheless, we have elected not to make an adjustment for these items because we cannot know whether the under-reporting is because those reporting some alcohol consumption just report far less than they actually consume, something we could handle by scaling up the estimated tax paid for each person, or because people who buy alcohol report no purchases at all. In this latter case, which seems more likely to us, we cannot know who in the HBS is hiding their consumption, so we cannot reliably assign the missing taxes to anyone in particular. We will show that poor people do pay indirect taxes in Tanzania, so the underreporting will cause us to underestimate the effect of these taxes on poverty. For 
inequality, the direction of bias is unclear: it is often assumed that excise taxes are regressive, but that is not always the case in developing countries especially for alcohol.

\section{iii. Description of Taxes and Expenditures in Tanzania}

Table 4 gives the breakdown of the major government revenue sources in 2011/12, the fiscal year that coincides most closely with the HBS. ${ }^{6}$ Overall revenues are small as a share of GDP, only 21 percent, though they are appreciable for a country at Tanzania's income level. Nevertheless, this limits government's ability to affect the distribution of income. Revenues come primarily from indirect taxes, especially VAT, the single largest source of revenue after grants, and excise duties, especially on petroleum products. Corporate income taxes, which we cannot include in our analysis, are rather small, while social insurance contributions are quite large, especially considering the small size of Tanzania's formal sector. Overall, our analysis treats tax items that account for $68.9 \%$ of total government revenues excluding grants and $11.2 \%$ of GDP.

It is much more difficult to attribute the expenditure side of the budget to specific beneficiaries. Governments spend significant amounts of their budgets on genuine public goods: national defense, law enforcement, and public administration. By their nature these goods and services are not attributable to individuals. The areas in which we can identify specific beneficiaries are usually social expenditures: transfer payments, health, and education. Table 5 gives a breakdown of expenditures in Tanzania in 2011/12 by central government, local government, and all pension funds. ${ }^{7}$ Overall, we can analyze only 28.6 percent of total expenditures (including social insurance) in our analysis, amounting to $9.0 \%$ of GDP. Education spending is by far the largest part of social spending in the analysis, followed by pensions and health spending.

\footnotetext{
${ }^{6}$ Note, however, that the contributions to social insurance come from calendar year 2013, the only year for which we could get these data. So the "budget" in this table does not correspond exactly to the 2011/12 fiscal year.

7 We were unable to identify and net out transfers from central to local government in the budget, so there is some double-counting of expenditures on local government items. The social insurance funds are independent of government, but we include their spending here to allow comparison to CEQ analyses in other countries.
} 
Younger, Myamba and Mdadila, WP 36, January 2016

TABLE 4 - GOVERNMENT REVENUES, TANZANIA, 2011/12, MILLION TZS

\begin{tabular}{|c|c|c|c|c|}
\hline Item & Amount & $\begin{array}{l}\% \text { of } \\
\text { GDP }\end{array}$ & $\begin{array}{l}\text { Included } \\
\text { in } \\
\text { analysis? }\end{array}$ & $\begin{array}{l}\text { Estimate } \\
\text { from HBS }\end{array}$ \\
\hline Total Revenue \& Grants & $8,695,951$ & $21.1 \%$ & & \\
\hline Revenue & $6,668,642$ & $16.2 \%$ & & \\
\hline Tax Revenue & $6,625,550$ & $16.1 \%$ & & \\
\hline $\mathrm{o} / \mathrm{w}$ Refunds and Transfers & 166,042 & $0.4 \%$ & & \\
\hline Tax Revenue (net) & $6,502,600$ & $15.8 \%$ & & \\
\hline Direct taxes of which & $2,430,208$ & $5.9 \%$ & & \\
\hline Corporate Income Tax & 751,687 & $1.8 \%$ & no & \\
\hline Payroll Tax (PAYE) & $1,129,469$ & $2.7 \%$ & yes & $1,177,232$ \\
\hline Skills Development Levy & 138,901 & $0.3 \%$ & yes & 67,786 \\
\hline Other Direct Taxes & 410,151 & $1.0 \%$ & partial & $17,378 / 1$ \\
\hline Contributions to Social Insurance of which $/ 2$ & $1,347,720$ & $3.3 \%$ & yes & $1,197,811$ \\
\hline From Employees & 465,358 & $1.1 \%$ & yes & \\
\hline From Employers & 882,362 & $2.1 \%$ & yes & \\
\hline From Self-Employed & - & & & \\
\hline Indirect Taxes of which & $4,029,301$ & $9.8 \%$ & & \\
\hline VAT & $1,975,545$ & $4.8 \%$ & yes & $1,972,045 / 3$ \\
\hline Excise Taxes & $1,419,383$ & $3.5 \%$ & yes & \\
\hline Petroleum & 872,399 & $2.1 \%$ & yes & 770,878 \\
\hline Bottled Water and Soft Drinks & 34,293 & $0.1 \%$ & yes & 27,192 \\
\hline Beer & 150,543 & $0.4 \%$ & yes & 2,816 \\
\hline Wine/Spirits/Konyagi & 53,217 & $0.1 \%$ & yes & 2,590 \\
\hline Tobacco & 78,502 & $0.2 \%$ & yes & 6,566 \\
\hline Communications & 116,237 & $0.3 \%$ & yes & 148,737 \\
\hline Other (imports) & 101,706 & $0.2 \%$ & no & \\
\hline Other & 12,486 & $0.0 \%$ & no & \\
\hline Import Duties & 497,687 & $1.2 \%$ & yes & $497,687 / 3$ \\
\hline Taxes on Exports & 36,601 & $0.1 \%$ & no & \\
\hline Other Indirect Taxes & 100,084 & $0.2 \%$ & no & \\
\hline Nontax Revenue & 43,091 & $0.1 \%$ & no & \\
\hline Revenue of Local Governments & 195,525 & $0.5 \%$ & no & \\
\hline Grants & $2,027,309$ & $4.9 \%$ & no & \\
\hline
\end{tabular}

Sources: Tanzania Revenue Authority, World Bank (2014) for social insurance collections, Economic Survey Book (2012) for local government revenue.

Notes: $1 /$ Includes only presumptive taxes paid by the non-agriculture self-employed.

2/ The administrative data here are for 2013 calendar year.

3/ Amount after scaling to administrative totals. 
Younger, Myamba and Mdadila, WP 36, January 2016

TABLE 5 -GOVERNMENT EXPENDITURES, TANZANIA, 2011/12, MILLION TZS

\begin{tabular}{|c|c|c|c|c|}
\hline Item & Amount & $\begin{array}{l}\% \text { of } \\
\text { GDP }\end{array}$ & $\begin{array}{l}\text { Included in } \\
\text { analysis? }\end{array}$ & $\begin{array}{l}\text { Estimate } \\
\text { from HBS }\end{array}$ \\
\hline Total Expenditure $/ 1$ & $12,902,764$ & $31.4 \%$ & & \\
\hline Defense Spending & 536,706 & $1.3 \%$ & no & \\
\hline Social Spending & $3,062,712$ & $7.4 \%$ & & \\
\hline Social Protection & 22,125 & $0.1 \%$ & & \\
\hline \multicolumn{5}{|l|}{ Social Assistance of which } \\
\hline Conditional or Unconditional Cash Transfers & 540 & $0.0 \%$ & no & \\
\hline Noncontributory Pensions & - & & & \\
\hline Near Cash Transfers & 37,800 & $0.1 \%$ & partial & $25,525 / 2$ \\
\hline \multicolumn{5}{|l|}{ Other } \\
\hline Social Insurance of which & 957,645 & $2.3 \%$ & & \\
\hline Old-Age Pensions & 943,501 & $2.3 \%$ & yes & $957,428 / 3$ \\
\hline Education of which & $1,891,092$ & $4.6 \%$ & & \\
\hline Pre-school & - & & yes & 95,778 \\
\hline Primary & 752,817 & $1.8 \%$ & yes & $1,051,832$ \\
\hline Secondary & 386,994 & $0.9 \%$ & yes & 409,279 \\
\hline Vocational & 44,177 & $0.1 \%$ & yes & 41,865 \\
\hline Post-secondary & 573,075 & $1.4 \%$ & yes & 416,630 \\
\hline Health of which & 643,150 & $1.6 \%$ & & \\
\hline Contributory & - & & & \\
\hline Noncontributory & 643,150 & $1.6 \%$ & yes & 607,868 \\
\hline Housing \& Urban of which & 6,392 & $0.0 \%$ & no & \\
\hline Housing & 6,392 & $0.0 \%$ & no & \\
\hline \multicolumn{5}{|l|}{ Subsidies of which } \\
\hline Energy of which & 341,096 & $0.8 \%$ & yes & \\
\hline Electricity & 185,904 & $0.5 \%$ & yes & 262,554 \\
\hline Fuel & 155,192 & $0.4 \%$ & yes & $/ 4$ \\
\hline Food & 28,500 & $0.1 \%$ & yes & 26,525 \\
\hline On Inputs for Agriculture (NAIVS) & 103,500 & $0.3 \%$ & yes & 50,962 \\
\hline Infrastructure of which & $2,783,558$ & $6.8 \%$ & no & \\
\hline Water \& Sanitation & 477,066 & $1.2 \%$ & no & \\
\hline Rural Roads & $2,306,492$ & $5.6 \%$ & no & \\
\hline Interest & $1,576,800$ & $3.8 \%$ & no & \\
\hline
\end{tabular}

Sources: Ministry of Finance, 2013; Controller and Auditor General, 2013; Development Policy Working Group, 2013; World Bank, 2011; World Bank, 2012; World Bank, 2014

Notes: 1/ Includes central government, social insurance spending by all pension funds, local government.

2/ This is the budget for NFRA only. Budgets for bed nets, school uniforms and books are unavailable.

3/ Amount after scaling to administrative totals.

4/ Included implicitly in the calculation of petroleum duties (netted out). 


\section{RESULTS}

\section{i. Inequality and Poverty}

Table 6 gives the Gini coefficients and headcount indices for three different PPP-based poverty lines for each CEQ income concept. Considering inequality first, there is little difference in the Gini coefficients for market income plus pensions, market income, and gross income. This indicates that pensions and direct transfers, including near cash transfers like NFRA and free school books and uniforms, do very little to reduce inequality in Tanzania. The Gini for net market income, however, is 2.1 to 2.4 points below the first three, indicating that direct taxes - PAYE, SDL, and selfemployment taxation - have a larger effect on inequality. Moving down the table, the next noticeable change in the Gini comes at disposable income less indirect taxes, showing that indirect taxes, VAT, import duties, and excises, also reduce inequality in Tanzania, albeit by a smaller amount (1.7 points). The transition from consumable income to final income, which shows the effect of inkind health and education benefits, also shows a small improvement in the Gini of 1.4 points. Overall, the activities of the fisc, or more precisely, those that we can include in the analysis, reduce inequality by 5.1 percentage points. This may not seem like much, but countries that are poorer and more equal ex ante tend to have relatively little redistribution (Lustig, 2015). Based on a regression of the difference in Gini for market income (plus pensions) and final income on GDP per capita at PPP market income inequality for all countries for which CEQ has completed an analysis, Tanzania's redistribution is actually 3 points better than predicted, a statistically significant result. As is clear from the table, most of this result is due to very progressive direct taxation, with indirect taxation and health and education benefits also contributing.

\section{TABLE 6 - GINI COEFFICIENTS AND POVERTY INDICES FOR CEQ INCOME CONCEPTS}

\begin{tabular}{|c|c|c|c|c|c|c|c|}
\hline & Poverty line: & $\mathrm{z}=\operatorname{Tsh} 36,482$ & per month & $\begin{array}{c}z=\operatorname{Tsh} 26,085 \\
\text { per month }\end{array}$ & $\begin{array}{l}\mathrm{z}=\$ 1.25 \\
\text { per day }\end{array}$ & $\begin{array}{l}z=\$ 2.50 \\
\text { per day }\end{array}$ & $\begin{array}{l}z=\$ 4.00 \\
\text { per day }\end{array}$ \\
\hline & Gini & $\begin{array}{c}\text { Headcount } \\
\text { index }\end{array}$ & $\begin{array}{c}\text { Poverty } \\
\text { Gap }\end{array}$ & $\begin{array}{c}\text { Headcount } \\
\text { index }\end{array}$ & $\begin{array}{c}\text { Headcount } \\
\text { index }\end{array}$ & $\begin{array}{c}\text { Headcount } \\
\text { index }\end{array}$ & $\begin{array}{c}\begin{array}{c}\text { Headcount } \\
\text { index }\end{array} \\
\end{array}$ \\
\hline Market Income plus Pensions & 0.382 & 0.283 & 0.068 & 0.101 & 0.437 & 0.835 & 0.937 \\
\hline Market Income* & 0.379 & 0.294 & 0.078 & 0.111 & 0.447 & 0.837 & 0.945 \\
\hline Gross Income & 0.381 & 0.280 & 0.067 & 0.097 & 0.432 & 0.833 & 0.937 \\
\hline Net Market Income & 0.358 & 0.285 & 0.069 & 0.101 & 0.441 & 0.845 & 0.947 \\
\hline Disposable Income & 0.357 & 0.282 & 0.067 & 0.097 & 0.436 & 0.844 & 0.940 \\
\hline Disposable Income plus Indirect Subsidies & 0.360 & 0.278 & 0.066 & 0.096 & 0.432 & 0.839 & 0.944 \\
\hline Disposable Income less Indirect Taxes & 0.341 & 0.353 & 0.092 & 0.145 & 0.521 & 0.889 & 0.960 \\
\hline Consumable Income & 0.345 & 0.348 & 0.090 & 0.144 & 0.515 & 0.883 & 0.963 \\
\hline Final Income & 0.331 & 0.250 & 0.053 & 0.073 & 0.416 & 0.855 & 0.954 \\
\hline
\end{tabular}

Source: HBS 2011/2012 and authors' calculations

Notes: Data in the columns with US\$ poverty lines at PPP are for per capita incomes to be comparable to other CEQ analyses; those in the columns with shilling poverty lines are per adult equivalent to be comparable to HBS publications. The national poverty line is TZS 36,482 per adult equivalent per month. The extreme poverty line is TZS 26,085.

Results for poverty are somewhat different. For all of the poverty lines considered in the table, there is relatively little movement in the headcount from market incomes plus pensions to disposable

8 These include Ethiopia, Tanzania, Ghana, Bolivia, Armenia, Guatemala, El Salvador, Indonesia, Peru, Colombia, South Africa, Brazil, Mexico, Uruguay, and Chile. 
income plus indirect subsidies. In particular, the cash and near-cash transfers that are meant to reduce poverty have very little effect, nor does the electricity subsidy. Disposable income plus indirect taxes, however, shows a large jump in the poverty measures across the table except at the highest international poverty line, which classifies almost everyone in Tanzania as poor. This shows that poor and almost poor households do pay indirect taxes - VAT, import duties, excises - and those taxes have a considerable negative effect on poverty in Tanzania. That effect is entirely or mostly reversed, depending on the poverty line, as we move to final income. A rough summary, then, is that government causes significant increases in poverty with the indirect taxes it levies, and at the national poverty lines, though not the highest international lines, causes a more than offsetting decrease in poverty with the in-kind health and education benefits it provides. Other activities of the fisc have only minor effects on poverty.

Overall, the fisc reduces poverty by 2.1 percentage points at the lowest $\$ 1.25$-per-day poverty line but actually increases poverty at the higher two international lines which count the majority of the population as "poor." At the national poverty line, the fisc reduces poverty by 3.3 percentage points. The reduction in extreme poverty is 2.8 percentage points. In both cases, this reduction comes about only because of the monetized value of in-kind education and health benefits that poor households receive in Tanzania. Without them, the fisc increases poverty.

Lustig (2015a) reports the change in the headcount ratio at the US $\$ 2.50$ per day poverty line for eleven Latin American countries from market income (plus pensions) to consumable income (not final). These range from a reduction of 3.8\% in Ecuador to an increase of $1.2 \%$ in Brazil and average a small reduction of $0.8 \%$. Table 6 shows that a similar calculation for Tanzania is an increase of $4.8 \%$, greater than any of the countries that Lustig reviews. In fact, regardless of which poverty line we use, poverty is higher for consumable income than market income in Tanzania. This highlights again the importance of in-kind benefits from education and health services in Tanzania's poverty reduction efforts: without them, the net effect of the fisc would be to increase poverty substantially.

\section{ii. Concentration Coefficients}

A tax or expenditure has a larger distributional impact if it is strongly targeted to the poor or the rich, and if it is large relative to incomes. ${ }^{9}$ Table 4 and Table 5 show how large is each of the items that we investigate relative to the budget and to GDP. Thus, we might expect that education expenditures or VAT may have large distributional consequences because they represent a large share of the budget and of GDP. But we also need to know how the benefits and costs of those items are distributed across the population - their incidence. Large taxes or expenditures that are distributed similarly to income will have little influence over the income distribution.

To that end, Figure 2 shows concentration coefficients for the tax and expenditure items that we analyze in this paper. Concentration coefficients are calculated like Gini coefficients: we order the

\footnotetext{
${ }^{9}$ Lustig, Enami, and Aranda (forthcoming) show that this statement is (i) true when the underlying income is the income that not only includes market income but also all the other components of fiscal policy and (ii) not strictly true if the tax or benefit generates a significant reranking of people in the income distribution. They give examples of transfers targeted to the poorest that are large enough to move them well up the income distribution and show that these transfers reduce the Gini less than similarly sized transfers spread more evenly across the population. Nevertheless, the size of taxes and transfers in Tanzania are such that the intuition of the text is adequate.
} 
population from poorest to richest and construction a concentration curve that shows the cumulative share of the taxes paid or benefits received across that income distribution. The concentration coefficient is the area between that concentration curve and an equal distribution (45degree line) multiplied by 2 . Unlike the Gini, a concentration coefficient can be negative. This indicates that the tax or benefit fall disproportionately on poorer people. In general, if we hope that fiscal policy will redistribute from the rich to the poor, then public expenditures should have more negative concentration coefficients and taxes should have more positive ones. In particular, it is customary to consider a tax to be regressive if its concentration coefficient is smaller than the Gini coefficient for the distribution of income ( 0.38 for market income plus pensions in Tanzania). If that is true but the concentration coefficient remains positive, poorer people pay a larger share of their income in tax, though the absolute amount they pay is smaller than for richer people. If the concentration coefficient is negative, poorer people pay a larger absolute amount of tax. The same is true of benefits from expenditures.

Tanzania's CCT has the only large negative concentration coefficient of -0.50 , meaning that this expenditure is strongly targeted to the poor as it should be. ${ }^{10}$ For comparison, similar cash transfer programs in middle income countries that also use a proxy means test for targeting average around 0.45 , while in rich countries the concentration coefficient is around -0.75 . It bears repeating that this is a simulation of beneficiaries because the number of actual beneficiaries in HBS 2012, when the CCT was still in a pilot phase, was very small. A concentration coefficient for actual beneficiaries will have to wait for the next round of the HBS.

The only other expenditures that go more to the poor on a per capita basis are the in-kind benefits of public pre-primary and primary schooling. This is typical of countries that have near universal coverage because some richer households opt out of the public school system in favor of private school, leaving the benefits of the publicly provided services to poorer households. Secondary school, whose coverage is far from universal, is less progressive than primary, and both vocational training and public university education are regressive: their benefits are highly concentrated among richer households. In fact, they are the only regressive expenditure in this study. ${ }^{11}$ These patterns are similar to those found in many countries and, indeed, to Tanzania's own past. They support the argument that, on equity grounds, it is better to subsidize lower levels of schooling than higher ones.

In-kind health services also become increasingly less progressive as we move from less- to moresophisticated services. Both out-patient and in-patient care at public dispensaries, the most basic service, are distributed equally across the income distribution, with concentration coefficients near zero. The coefficients for public health centers and hospitals are larger, though none of these services is regressive. Note also that at each type of institution, out-patient services are more progressive than in-patient care. This, too, is a typical pattern in developing countries.

\footnotetext{
10 We were concerned that this assessment is too optimistic because the PMT formula was estimated on the $2011 / 12$ HBS, the same survey we use. As such, the PMT formula is tuned to the 2011/12 data, including its errors. To test this, we applied the PMT formula to the second wave of the National Panel Survey, collected in 2010/11. The concentration coefficient for simulated CCT receipts in that survey was almost as low as the one we report here, -0.47 .

11 Pension receipts are also highly concentrated among the rich, which is to be expected since they are tied to formal sector employment. But in Tanzania, these are not so much transfer payments as deferred compensation. We have included them here only for illustrative purposes.
} 
It is interesting that none of the near-cash transfers has a negative concentration coefficient even though all of these programs intend to help poorer households. We should recall, however, that the HBS does not distinguish the source of these transfers, so it is possible that assistance from government for these items is more (or less) progressive than assistance from NGOs, family members, etc.

Neither of the indirect subsidies in Tanzania, on fertilizer and electricity, goes disproportionately to the poor. In fact, the electricity subsidy is regressive, with a very large concentration coefficient, despite the lifeline tariff structure. The fertilizer subsidy is not targeted explicitly to the poor, but rather to farmers who are best able to make good use of fertilizer. But one might hope that because farming households are usually poorer than others, this subsidy might be well-targeted to the poor. But that is not the case in Tanzania.

\section{FIGURE 2 - CONCENTRATION COEFFICIENTS OVER MARKET INCOME PLUS PENSIONS}

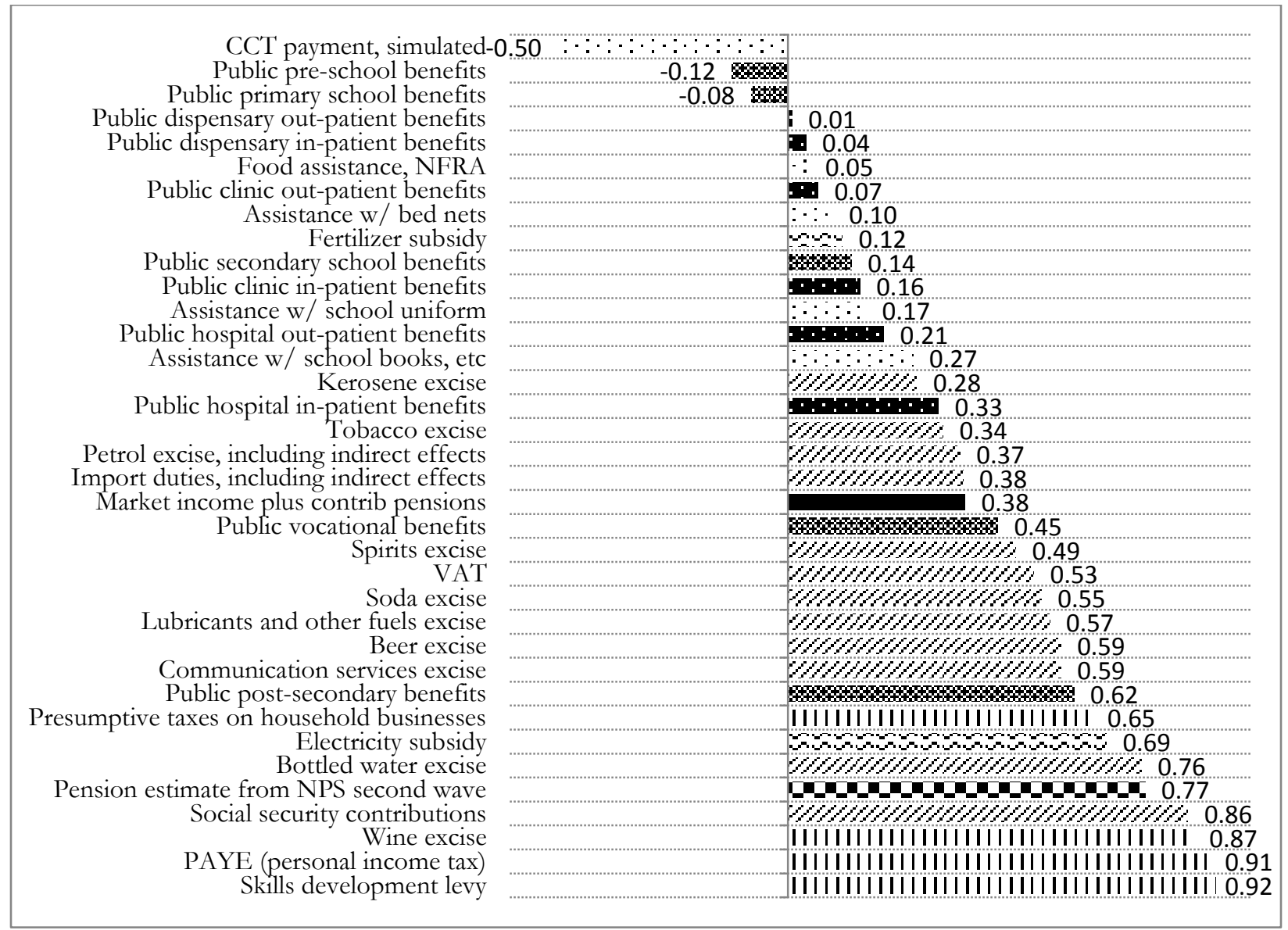

Source: HBS 2012 and authors' calculations

For taxes, Tanzania has two regressive taxes: the excise duties on kerosene and on tobacco products. Poor households' budget shares for kerosene are typically larger than richer households'. In response, some governments levy lower excises on kerosene than other petroleum products on equity grounds, but Tanzania actually taxes kerosene more heavily than petrol or diesel (Table 2). Tobacco taxation presents a dilemma: for equity purposes, it would be good to lower these taxes, but there are negative externalities associated with tobacco consumption, so there are efficiency reasons to tax tobacco, perhaps heavily. 
Petrol excises and import duties are roughly neutral and thus will have very little effect on inequality, but a perhaps substantial effect on poverty since poor households pay a share of these taxes that is proportionate to their share of income. This may seems surprising, but recall that these estimates include the indirect effect of these taxes on goods and services that use petrol and imports as intermediate inputs.

All the other taxes are progressive, some extraordinarily so. VAT and all the remaining excises are moderately progressive. Note in particular that the other "sin" tax, alcohol excises, is progressive and thus does not present the same policy dilemma as the tobacco excise: increasing these taxes will improve both equity and efficiency. ${ }^{12}$ Bottled water and soda excises are also progressive, as is the communications tax.

The direct taxes on formal sector workers, PAYE and SDL, are extremely progressive, in part because Tanzania has a progressive rate structure, but mostly because these taxes fall on formal sector employees who tend to be much better off than the rest of the population. Taxes on the selfemployed are also highly progressive, but not so much as PAYE and SDL. Even though most of these enterprises are informal, their owners are better off than the general population.

\section{iii. How Does Tanzania Compare to Other Countries?}

CEQ has completed analyses more than 20 countries around the world, though most are in Latin America. Table 7 gives comparative information for all the studies in low, lower-middle, and African countries completed to date. It is important to note that these data are derived entirely from the respective household surveys, not administrative accounts. Tanzania starts as one of the poorer and, ex ante, more equal countries in this group, characteristics which, as we have noted, would lead us to expect it to redistribute less. But as Table 6 shows, Tanzania actually achieves substantial reductions in inequality. That redistribution requires both significant budget shares and good targeting, so Table 7 provides information on both.

12 This is subject to the caveat that alcohol consumption is greatly underreported in the HBS. 
Younger, Myamba and Mdadila, WP 36, January 2016

TABLE 7 - BUDGETS AND TARGETING IN LOWER-MIDDLE-INCOME CEQ COUNTRIES

\begin{tabular}{|c|c|c|c|c|c|c|c|c|c|c|}
\hline & $\begin{array}{c}\text { Ethiopia } \\
(2011)\end{array}$ & $\begin{array}{c}\text { Tanzania } \\
(2012) \\
\end{array}$ & $\begin{array}{c}\text { Ghana } \\
(2013) / 1\end{array}$ & $\begin{array}{r}\text { Bolivia } \\
(2009)\end{array}$ & $\begin{array}{c}\text { Guatemala } \\
(2010)\end{array}$ & $\begin{array}{c}\text { Armenia } \\
(2011)\end{array}$ & $\begin{array}{c}\text { El } \\
\text { Salvador } \\
(2011) \\
\end{array}$ & $\begin{array}{l}\text { Indonesia } \\
(2012) 1 / \\
\end{array}$ & $\begin{array}{c}\text { South } \\
\text { Africa } \\
(2010) 2 / \\
\end{array}$ & Average \\
\hline \multirow[t]{2}{*}{ GNI per capita (2011 PPP) } & $\$ 1,163$ & $\$ 2,201$ & $\$ 3,737$ & $\$ 5,090$ & $\$ 6,474$ & $\$ 7,045$ & $\$ 7,389$ & $\$ 9,017$ & $\$ 11,833$ & $\$ 5,994$ \\
\hline & \multicolumn{10}{|c|}{$\%$ of GDP } \\
\hline Direct Taxes & $3.9 \%$ & $5.9 \%$ & $6.7 \%$ & $5.7 \%$ & $3.3 \%$ & $5.2 \%$ & $5.2 \%$ & $5.6 \%$ & $14.3 \%$ & $6.2 \%$ \\
\hline Indirect and Other Taxes & $7.8 \%$ & $9.8 \%$ & $7.8 \%$ & $21.1 \%$ & $8.9 \%$ & $11.9 \%$ & $10.3 \%$ & $6.3 \%$ & $12.8 \%$ & $10.7 \%$ \\
\hline Cash and Near-cash Transfers & $1.3 \%$ & $0.3 \%$ & $0.2 \%$ & $2.0 \%$ & $0.5 \%$ & $2.5 \%$ & $1.4 \%$ & $0.4 \%$ & $3.8 \%$ & $1.4 \%$ \\
\hline Education Spending & $4.6 \%$ & $4.6 \%$ & $5.7 \%$ & $8.3 \%$ & $2.6 \%$ & $3.5 \%$ & $2.9 \%$ & $3.4 \%$ & $7.0 \%$ & $4.7 \%$ \\
\hline Health Spending & $1.2 \%$ & $1.6 \%$ & $1.7 \%$ & $3.6 \%$ & $2.4 \%$ & $1.7 \%$ & $4.3 \%$ & $0.9 \%$ & $4.1 \%$ & $2.4 \%$ \\
\hline \multirow[t]{2}{*}{ Gini, Market Income } & 0.32 & 0.38 & 0.44 & 0.50 & 0.55 & 0.47 & 0.44 & 0.39 & 0.77 & 0.47 \\
\hline & \multicolumn{10}{|c|}{ Concentration Coefficients } \\
\hline Direct Taxes & 0.60 & 0.91 & 0.73 & n.a. & 0.85 & 0.62 & 0.82 & n.a. & 0.90 & 0.77 \\
\hline Indirect and Other Taxes & 0.37 & 0.47 & 0.44 & 0.37 & 0.43 & 0.38 & 0.42 & 0.35 & 0.69 & 0.44 \\
\hline Cash and Near-cash Transfers & -0.37 & 0.10 & -0.37 & -0.07 & -0.31 & -0.30 & -0.27 & -0.25 & -0.27 & -0.23 \\
\hline \multicolumn{11}{|l|}{ Education } \\
\hline Pre-primary & n.a. & -0.12 & -0.34 & -0.21 & -0.10 & -0.05 & -0.20 & n.a. & -0.11 & -0.16 \\
\hline Primary & -0.03 & -0.08 & -0.27 & -0.25 & -0.18 & -0.18 & -0.22 & -0.08 & -0.19 & -0.16 \\
\hline Secondary & 0.27 & 0.14 & 0.01 & -0.12 & 0.03 & -0.04 & 0.02 & $\ldots$ & -0.12 & 0.02 \\
\hline Tertiary & 0.41 & 0.62 & 0.62 & 0.30 & 0.59 & 0.25 & 0.44 & 0.47 & 0.50 & 0.47 \\
\hline Health & 0.07 & 0.18 & 0.04 & -0.04 & 0.18 & 0.01 & 0.12 & 0.12 & -0.06 & 0.07 \\
\hline Indirect Subsidies & 0.40 & 0.59 & 0.43 & 0.37 & 0.10 & n.a. & n.a. & 0.34 & & 0.37 \\
\hline
\end{tabular}

Sources: Inchauste and Lustig, forthcoming; Younger, Osei-Assibey, and Oppong, 2015 for Ghana; this study for Tanzania

In terms of government's taxation and spending, Tanzania is a little below the average for these countries on most items but, given its relative poverty, actually takes in more than one would expect in both direct and indirect taxes. Education spending is about on par with the other countries, while health spending is, again, below average, but similar to the other poorer countries in the sample.

The incidence of direct taxes in Tanzania is more progressive than any other country in the table. Incidence of indirect taxes is second only to South Africa, which starts from a much less equal income distribution. In fact, if we consider taxes to be progressive only if they have a concentration coefficient greater than the Gini, then only Ethiopia and Tanzania have progressive indirect taxes. Overall then, the effect of taxation on the income distribution in Tanzania is the most progressive of these countries.

The results for expenditures are much less positive. For education at every level Tanzania's spending is among the least progressive these countries, as is health spending. Indirect subsidies, primarily for electricity in Tanzania, are notable for their regressivity, as is spending on tertiary education.

\section{iv. Coverage}

A public expenditure's coverage rate is the number of beneficiaries divided by the target population. When subdivided by income groups, this information is a useful complement to the incidence analysis presented so far. In particular, good targeting alone is not sufficient to guarantee high coverage for the poor. The program size (expenditure) must also be sufficiently large. Coverage information can also show leakage of benefits to non-target populations, and indicate whether certain sub-populations are more or less likely to benefit from public services like health and education that should be universal. 
Table 8 gives coverage rates for social expenditures in Tanzania. Education coverage is low for all but primary school. ${ }^{13}$ It is more difficult to judge whether the coverage of health care is adequate, but we note that public health centers have lower coverage than either dispensaries or hospitals. Access to the electric mains and clean water are also low. And almost no one who is over 60 years old receives a pension. Overall, coverage for most public services is low, especially for the poor and even for those services we find are well-targeted to the poor. There is still considerable room, then, to increase the well-targeted services and thus have a significant effect on poverty and inequality.

TABLE 8 - COVERAGE RATES, TANZANIA, 2011/12

\begin{tabular}{|c|c|c|c|c|c|}
\hline Income group: & $y<\$ 1.25$ & $\begin{array}{l}\$ 1.25< \\
y \\
<\$ 2.50\end{array}$ & $\begin{array}{l}\$ 2.50< \\
y \\
<\$ 4.00\end{array}$ & $\begin{array}{l}\$ 4.00< \\
y \\
<\$ 10.00\end{array}$ & $\$ 10.00<y$ \\
\hline \multicolumn{6}{|l|}{ Education } \\
\hline Pre-school, public & 0.15 & 0.13 & 0.14 & 0.10 & 0.07 \\
\hline Pre-school & 0.16 & 0.17 & 0.24 & 0.24 & 0.44 \\
\hline Primary, public & 0.68 & 0.77 & 0.76 & 0.63 & 0.51 \\
\hline Primary & 0.69 & 0.80 & 0.82 & 0.86 & 0.87 \\
\hline Secondary, Public & 0.23 & 0.33 & 0.38 & 0.38 & 0.27 \\
\hline Secondary & 0.24 & 0.39 & 0.51 & 0.58 & 0.59 \\
\hline \multicolumn{6}{|l|}{ Health } \\
\hline Hospital & 0.03 & 0.06 & 0.08 & 0.11 & 0.15 \\
\hline Hospital, public & 0.02 & 0.03 & 0.04 & 0.07 & 0.08 \\
\hline Center & 0.02 & 0.03 & 0.03 & 0.03 & 0.03 \\
\hline Center, public & 0.01 & 0.02 & 0.02 & 0.02 & 0.02 \\
\hline Dispensary & 0.05 & 0.06 & 0.07 & 0.05 & 0.04 \\
\hline Dispensary, public & 0.05 & 0.05 & 0.05 & 0.03 & 0.01 \\
\hline \multicolumn{6}{|l|}{ Social Security } \\
\hline Pension & 0.00 & 0.01 & 0.02 & 0.03 & 0.02 \\
\hline \multicolumn{6}{|l|}{ Infrastructure } \\
\hline Electric mains & 0.04 & 0.16 & 0.41 & 0.60 & 0.82 \\
\hline Piped water or borehole & 0.33 & 0.41 & 0.59 & 0.64 & 0.75 \\
\hline Note: population shares: & 0.44 & 0.40 & 0.10 & 0.05 & 0.01 \\
\hline
\end{tabular}

Source: HBS 2012 and authors' calculations

\footnotetext{
13 We define coverage as all students at a given level divided by students of the appropriate age for that level plus students of other ages attending that level. This cannot exceed one as gross enrolment rates can.
} 
Younger, Myamba and Mdadila, WP 36, January 2016

\section{v. Income Mobility}

Most fiscal incidence studies focus on expenditures; some examine taxes; but relatively few look at both. While either expenditures or taxes can be progressive and thus make the income distribution more equal, only expenditures can reduce poverty. Taxes at best leave it unchanged. This means that the fiscal system as a whole may increase or decrease any individual's income on net, and may move her/him up or down the income distribution. Most measures used to evaluate fiscal incidence are anonymous: they do not consider who is in the $\mathrm{p}^{\text {th }}$ quantile of the income distribution, only the income that that $\mathrm{p}^{\text {th }}$ person has.

Lustig (forthcoming) proposes the use of mobility matrices to describe the extent to which the fiscal system increases or decreases people's incomes. Table 9 gives these matrices for mobility from market income to disposable income, consumable income, and final income where the income ranges are defined by PPP\$ poverty lines standard to the CEQ analysis. ${ }^{14}$

\section{TABLE 9 - MOBILITY MATRICES BY INCOME GROUP, MARKET INCOME TO DISPOSABLE, CONSUMABLE, AND FINAL INCOME}

\begin{tabular}{|c|c|c|c|c|c|c|c|}
\hline \multirow[b]{2}{*}{ Market Income groups } & \multicolumn{6}{|c|}{ Disposable Income groups } & \multirow[b]{2}{*}{$\begin{array}{l}\text { Average } \\
\text { Market } \\
\text { Income } \\
\text { (TZS per mo) }\end{array}$} \\
\hline & $\begin{array}{l}y<< \\
\$ 1.25\end{array}$ & $\begin{array}{l}\$ 1.25 \\
<=y< \\
\$ 2.50\end{array}$ & $\begin{array}{l}\$ 2.50 \\
<=y< \\
\$ 4.00\end{array}$ & $\begin{array}{l}\$ 4.00 \\
<=y< \\
\$ 10.00\end{array}$ & $\begin{array}{l}>= \\
\$ 10.00\end{array}$ & $\begin{array}{l}\text { Percent of } \\
\text { Population }\end{array}$ & \\
\hline$y<\$ 1.25$ & $99 \%$ & $1 \%$ & $0 \%$ & $0 \%$ & $0 \%$ & $44 \%$ & 25,492 \\
\hline$\$ 1.25<=\mathrm{y}<\$ 2.50$ & $1 \%$ & $99 \%$ & $0 \%$ & $0 \%$ & $0 \%$ & $40 \%$ & 49,911 \\
\hline$\$ 2.50<=\mathrm{y}<\$ 4.00$ & $0 \%$ & $8 \%$ & $92 \%$ & $0 \%$ & $0 \%$ & $10 \%$ & 89,585 \\
\hline$\$ 4.00<=$ y $<\$ 10.00$ & $0 \%$ & $4 \%$ & $13 \%$ & $83 \%$ & $0 \%$ & $5 \%$ & 163,444 \\
\hline \multirow[t]{2}{*}{$>=\$ 10.00$} & $0 \%$ & $3 \%$ & $1 \%$ & $32 \%$ & $65 \%$ & $1 \%$ & 512,202 \\
\hline & \multicolumn{7}{|c|}{ Consumable Income groups } \\
\hline $\mathrm{y}<\$ 1.25$ & $100 \%$ & $0 \%$ & $0 \%$ & $0 \%$ & $0 \%$ & $44 \%$ & 25,492 \\
\hline$\$ 1.25<=\mathrm{y}<\$ 2.50$ & $19 \%$ & $80 \%$ & $0 \%$ & $0 \%$ & $0 \%$ & $40 \%$ & 49,911 \\
\hline$\$ 2.50<=\mathrm{y}<\$ 4.00$ & $0 \%$ & $44 \%$ & $56 \%$ & $0 \%$ & $0 \%$ & $10 \%$ & 89,585 \\
\hline$\$ 4.00<=y<\$ 10.00$ & $0 \%$ & $6 \%$ & $41 \%$ & $53 \%$ & $0 \%$ & $5 \%$ & 163,444 \\
\hline \multirow[t]{2}{*}{$>=\$ 10.00$} & $1 \%$ & $2 \%$ & $2 \%$ & $57 \%$ & $39 \%$ & $1 \%$ & 512,202 \\
\hline & \multicolumn{7}{|c|}{ Final Income groups } \\
\hline $\mathrm{y}<\$ 1.25$ & $90 \%$ & $10 \%$ & $0 \%$ & $0 \%$ & $0 \%$ & $44 \%$ & 25,492 \\
\hline$\$ 1.25<=\mathrm{y}<\$ 2.50$ & $6 \%$ & $91 \%$ & $3 \%$ & $0 \%$ & $0 \%$ & $40 \%$ & 49,911 \\
\hline$\$ 2.50<=\mathrm{y}<\$ 4.00$ & $0 \%$ & $29 \%$ & $67 \%$ & $4 \%$ & $0 \%$ & $10 \%$ & 89,585 \\
\hline$\$ 4.00<=y<\$ 10.00$ & $0 \%$ & $5 \%$ & $35 \%$ & $60 \%$ & $0 \%$ & $5 \%$ & 163,444 \\
\hline$>=\$ 10.00$ & $1 \%$ & $1 \%$ & $2 \%$ & $53 \%$ & $44 \%$ & $1 \%$ & 512,202 \\
\hline
\end{tabular}

Source: HBS 2012 and authors' calculations

\footnotetext{
${ }^{14} \mathrm{It}$ is important to remember that the analysis includes quite a bit more of taxes (12\% of GDP) than it does in benefits ( $9 \%$ of GDP) so there is, on average, a bias towards lowering incomes.
} 
Younger, Myamba and Mdadila, WP 36, January 2016

The remarkable thing about this table is that, except for the move to final income, which includes in-kind education and health benefits, the fisc induces almost no upward mobility, while it does move significant shares of the higher income groups downward, even those who start out in the $\$ 1.25$-to$\$ 2.50$ per day range. Even including in-kind benefits, many more people move down than up in all of the income groups except the poorest.

\section{vi. $\quad$ Comparisons to Other Incidence Studies in Tanzania}

Despite policy makers' regular concern for poverty reduction and equity, we found surprisingly few studies that examine the incidence of taxes and social expenditures in Tanzania. Table 10 summarizes these studies' results. The current study shows direct taxes, PAYE, to be significantly less progressive than the results for 2001/02 in Mtei, et.al. (2012), as is the current incidence of import duties. Otherwise, these two studies have similar concentration coefficients for taxes. The study by Sahn and Younger (1999) also produces concentration coefficients for taxes that are very similar to the ones in this study, despite using data from 1993. Overall, then, the incidence of indirect taxes seems to be quite stable over time in Tanzania, while that for direct taxes is somewhat less progressive today than was previously true, perhaps due to an expansion of the formal sector of the economy.

For education expenditures, we can compare only primary and secondary schooling in the current study with the results from 1993 in Sahn and Younger. Both expenditures are more progressive today than they were 20 years ago. This is a common, though not necessary result, when the coverage of a public service expands. ${ }^{15}$ When relatively few children attend public schools, they are usually the children of richer households. As coverage expands, children from poorer households begin to attend school, and its incidence becomes more progressive. In addition, as schooling expands, some richer households elect private schools, which makes the incidence of public schools even more progressive, something that has happened especially in primary schools in Tanzania (Table 8).

For health expenditures, results from this study are very close to those in Sahn and Younger for 1993, though somewhat less progressive than the results in Mtei, et.al. (2012) and Makawia et.al., (2010) for 2001/02 and 2008, respectively. Thus, despite efforts to improve access to health care, that care is not becoming more progressive over in the same way that primary schooling is.

15 Lopez-Calva, et.al. (2014) find a similar result for Mexico, as do Younger, Osei-Assibey, and Oppong (2015) for Ghana. 
Younger, Myamba and Mdadila, WP 36, January 2016

TABLE 10 - SUMMARY OF INCIDENCE STUDIES IN TANZANIA

\begin{tabular}{|c|c|c|c|c|c|}
\hline Source: & \multicolumn{2}{|l|}{ this study } & $\begin{array}{l}\text { Sahn and } \\
\text { Younger, } \\
1999\end{array}$ & $\begin{array}{l}\text { Mtei, } \\
\text { et.al. } 2012\end{array}$ & $\begin{array}{l}\text { Makawia, } \\
\text { et.al. } \\
2010\end{array}$ \\
\hline dataset(s) and year: & \multicolumn{2}{|c|}{ HBS, 2011/12 } & $\begin{array}{l}\text { HRD } \\
1993\end{array}$ & $\begin{array}{l}\text { HBS } \\
2001 / 02\end{array}$ & $\begin{array}{l}\text { SHIELD, } \\
2008\end{array}$ \\
\hline household expenditures scaled by: & per capita & $\begin{array}{l}\text { per adult } \\
\text { equivalent }\end{array}$ & $\begin{array}{l}\text { per } \\
\text { capita }\end{array}$ & $\begin{array}{l}\text { per adult } \\
\text { equivalent }\end{array}$ & $\begin{array}{l}\text { socio- } \\
\text { economic } \\
\text { status }\end{array}$ \\
\hline Gini coefficient, $\mathrm{HH}$ expenditures & 0.36 & 0.34 & 0.39 & 0.42 & \\
\hline \multicolumn{6}{|l|}{ Taxes } \\
\hline PAYE & 0.63 & 0.61 & & 0.95 & \\
\hline Self-employment presumptive tax & 0.65 & 0.64 & & & \\
\hline VAT / Sales tax & 0.53 & 0.51 & 0.47 & 0.46 & \\
\hline Import duties & 0.38 & 0.36 & & 0.57 & \\
\hline All excises & 0.59 & 0.59 & & 0.55 & \\
\hline Tobacco excise & 0.34 & 0.32 & 0.39 & & \\
\hline Alcohol excise & 0.62 & 0.62 & 0.58 & & \\
\hline Soda excise & 0.55 & 0.53 & & & \\
\hline Gasoline (direct effect only) & 0.86 & 0.85 & 0.93 & & \\
\hline Fuel (indirect via personal transport) & 0.61 & 0.59 & 0.60 & & \\
\hline Gasoline (direct and indirect) & 0.37 & 0.36 & & & \\
\hline Kerosene & 0.28 & 0.26 & 0.36 & & \\
\hline \multicolumn{6}{|l|}{ All petroleum duties } \\
\hline \multicolumn{6}{|l|}{ Expenditures } \\
\hline ССТ & -0.50 & -0.50 & & & \\
\hline Fertilizer subsidy & 0.12 & 0.10 & & & \\
\hline \multicolumn{6}{|l|}{ Education } \\
\hline Public Primary & -0.08 & -0.09 & 0.00 & & \\
\hline Public Secondary & 0.14 & 0.04 & 0.31 & & \\
\hline Public Vocational & 0.45 & 0.37 & & & \\
\hline \multicolumn{6}{|l|}{ Health } \\
\hline Public dispensary, outpatient & 0.01 & 0.02 & & & \\
\hline Public dispensary, inpatient & 0.04 & 0.06 & & & \\
\hline Public clinic/health centre, outpatient & 0.07 & 0.08 & & & \\
\hline Public clinic/health centre, inpatient & 0.16 & 0.11 & & & \\
\hline Public health centres & 0.05 & 0.05 & 0.08 & -0.10 & -0.10 \\
\hline District hospital, outpatient & & & & & 0.15 \\
\hline District hospital, inpatient & & & & 0.15 & -0.17 \\
\hline Regional/teaching hospital, outpatient & & & & & 0.14 \\
\hline Regional/teaching hospital, inpatient & & & & 0.14 & 0.29 \\
\hline All public hospitals & 0.26 & 0.25 & 0.24 & & \\
\hline All public hospitals, outpatient & 0.21 & 0.19 & & & \\
\hline All public hospitals, inpatient & 0.33 & 0.33 & & & \\
\hline
\end{tabular}

Notes: The SHIELD survey is not a nationally representative sample.

Results for this study in this table are ranked by disposable income, not market income, to be more comparable to the other studies. 


\section{POLICY SIMULATIONS}

In addition to describing the status quo, it is possible to use incidence analysis to simulate the distributional consequences of policy changes. In this section, we consider four such simulations, two that address recent discussions of social protection policy and two suggested by the results here.

\section{i. $\quad$ Eliminate Electricity Subsidies}

The one government expenditure that stands out in Figure 2 as being extremely regressive is the electricity subsidy. Furthermore, Tanzania's Big Results Now Energy Lab proposes eliminating all recurrent energy subsidies by 2015/16 (Ministry of Energy and Minerals, 2013), so it is timely to assess the distributional impact of removing subsidies to electricity consumption. TABLE 11 presents four simulations of that policy.

\section{TABLE 11 - SIMULATED REMOVAL OF ELECTRICITY SUBSIDIES}

\begin{tabular}{llllll}
\hline \multirow{5}{*}{ Change in: } & & $(1)$ & $(2)$ & $(3)$ & $(4)$ \\
\hline Extreme & Disposable Income & & & -0.0164 & -0.0058 \\
Poverty & Consumable Income & 0.0007 & 0.0005 & -0.0185 & -0.0053 \\
Headcount & Final Income & 0.0001 & 0.0001 & -0.0117 & -0.0017 \\
\hline \multirow{2}{*}{$\begin{array}{l}\text { Poverty } \\
\text { Headcount }\end{array}$} & Disposable Income & & & -0.0140 & -0.0022 \\
& Consumable Income & 0.0029 & 0.0024 & -0.0148 & -0.0004 \\
& Final Income & 0.0019 & 0.0013 & -0.0163 & -0.0031 \\
\hline \multirow{2}{*}{ Poverty } & Disposable Income & & & -0.0080 & -0.0023 \\
Gap & Consumable Income & 0.0006 & 0.0004 & -0.0089 & -0.0019 \\
& Final Income & 0.0003 & 0.0002 & -0.0064 & -0.0017 \\
\hline \multirow{2}{*}{ Gini } & Disposable Income & & & -0.0068 & -0.0018 \\
& Consumable Income & -0.0036 & -0.0020 & -0.0108 & -0.0055 \\
& Final Income & -0.0034 & -0.0019 & -0.0094 & -0.0050 \\
\hline Budgetary savings (\% of GDP): & $0.43 \%$ & $0.27 \%$ & $0.00 \%$ & $0.34 \%$ \\
\hline
\end{tabular}

Simulation Descriptions:

(1) Eliminates the Electricity Subsidy with no compensation.

(2) Eliminates subsidy except for lifeline tariff for first $50 \mathrm{kwh}$, which is held constant.

(3) Eliminates electricity subsidy and uses all the funds to expand CCT coverage by raising the proxy means test (PMT) threshold.

(4) Eliminates electricity subsidy and uses enough funds to expand CCT to leave poverty roughly unchanged. Note: All changes are absolute changes in the poverty and inequality measures.

The first simulation simply eliminates the subsidy. This generates a small improvement in inequality, but also small increases in poverty. Even though most electricity consumption occurs at the upper end of the income distribution, poor (and almost poor) people do consume some electricity, so 
removing the subsidy hurts them and increases poverty, albeit slightly. ${ }^{16}$ This results is sometimes used to criticize subsidy removal.

The second simulation removes all of the subsidy except the lifeline tariff which is left in place, a policy that is sometimes proposed to protect the poor. But most of the poverty measures increase by almost as much in this simulation as in the first; the lifeline tariff does not do a very good job of protecting the poor. It does, however, reduce the amount the government can save by more than a third, from $0.43 \%$ of GDP to $0.27 \%$.

The third simulation eliminates the electricity subsidy and uses the funds saved, $0.43 \%$ of GDP, to expand the CCT by raising the eligibility threshold for the proxy means test (PMT) until all of the savings are expended on new CCT recipients. ${ }^{17}$ This has a substantial effect on poverty (and inequality) reduction, highlighting the fact that, if the intention of the electricity subsidy is to help the poor, it is money poorly spent. It would be much more effective to expand the CCT.

The fourth simulation also eliminates the electricity subsidy and increases the coverage of the CCT, but this time only by enough to keep poverty from increasing. ${ }^{18}$ The interesting result here is in the last row: government can eliminate the electricity subsidy, keep poverty constant by increasing coverage of the CCT, and still save $0.34 \%$ of GDP.

In sum, government has excellent options to improve its budgetary situation and/or reduce poverty by eliminating electricity subsidies.

\section{ii. Expand Coverage of Conditional Cash Transfers}

Tanzania's pilot CCT program was reasonably successful at reducing participants' poverty levels (Evans, et.al., 2013), and the results in Figure 2 show that the CCT is extremely well-targeted to the poor, so there is interest in scaling the program up. TABLE 12 simulates three possible ways of scaling up Tanzania's CCT so that its total expenditures would be $0.5 \%$ of GDP, an amount that is typical for lower-middle income countries. The first simulation expands the CCT to all vulnerable children and elderly people, regardless of their score on the PMT. This would require almost 1\% of GDP in additional expenditures so, to keep the budget to $0.5 \%$ of GDP, we scale down the benefits for each recipient. The second simulation expands the program to eligible participants by raising the PMT threshold until the additional expenditures total 0.5\% of GDP. The third simulation opens the CCT to all people, not just vulnerable children and the elderly, and raises the PMT threshold until the additional expenditures total $0.5 \%$ of GDP.

\footnotetext{
${ }^{16}$ In fact, because a subsidy removal (or imposition of a tax) only takes resources away from households, it cannot reduce poverty. The best possible outcome for these policies would be no change in poverty if poor and almost poor households consume none of the previously subsidized good.

17 The threshold increases from 10.57 (about the eighth percentile of the PMT distribution) to 10.88 (about the twentyfifth percentile).

18 Because the different poverty measures change by different amounts, it is not possible to run one simulation that keeps all of them at zero. Here, we keep the measure that deteriorated the most in the first simulation, the headcount for consumable income, nearly constant, while the other show small improvements.
} 
Younger, Myamba and Mdadila, WP 36, January 2016

\section{TABLE 12 - SIMULATED EFFECTS OF INCREASING CCT COVERAGE}

Simulation

\begin{tabular}{lllll} 
Change in: & & $(1)$ & $(2)$ & $(3)$ \\
\hline Extreme & Disposable Income & -0.011 & -0.017 & -0.021 \\
Poverty & Consumable Income & -0.010 & -0.018 & -0.023 \\
Headcount & Final Income & -0.008 & -0.012 & -0.017 \\
\hline \multirow{2}{*}{ Poverty } & Disposable Income & -0.015 & -0.016 & -0.024 \\
Headcount & Consumable Income & -0.010 & -0.014 & -0.014 \\
& Final Income & -0.012 & -0.016 & -0.019 \\
\hline \multirow{3}{*}{ Poverty Gap } & Disposable Income & -0.006 & -0.009 & -0.011 \\
& Consumable Income & -0.006 & -0.009 & -0.011 \\
& Final Income & -0.004 & -0.006 & -0.009 \\
\hline \multirow{3}{*}{ Gini } & Disposable Income & -0.004 & -0.007 & -0.009 \\
& Consumable Income & -0.006 & -0.009 & -0.011 \\
& Final Income & -0.005 & -0.008 & -0.010 \\
\hline & Note: Scaling Factor & 0.55 & 1.00 & 1.00 \\
\hline
\end{tabular}

Simulation Descriptions:

(1) Expands CCT to all eligible persons, then scales benefits down so the total CCT expenditure is $0.5 \%$ of GDP

(2) Expands CCT at current benefit rates to the poorest eligible people according to the proxy means test until total CCT payments are $0.5 \%$ of GDP.

(3) Expands CCT at current benefit rates to the poorest people regardless of VC/elderly according to the proxy means test until total CCT payments are $0.5 \%$ of GDP.

Notes: All simulations increase VAT to pay for the additional benefits.

All changes are absolute changes in the poverty and inequality measures.

The first simulation would seem to be the least effective approach to an expansion because some of the vulnerable children and the elderly are not poor to begin with, and the additional VAT and reduced benefits levels used to finance the program expansion will impoverish some people. Nevertheless, this simulation does reduce extreme poverty by about one percentage point, and poverty by a little more.

The second simulation has a larger effect on both poverty and inequality, as is to be expected since it limits benefits to those with lower PMT scores. The third simulation does even better, suggesting that the government could improve the CCT's targeting by eliminating the restriction of benefits to vulnerable children and the elderly, focusing instead only on those with low PMT scores. But regardless of the approach, a fairly limited expansion of the CCT to $0.5 \%$ of GDP would have significant effects on poverty and inequality in Tanzania, a reflection of this programs' excellent targeting.

\section{Establish a Social Pension}

Osberg and Mboghoina (2011) argue that even though the extended family remains strong in Tanzania, there are good reasons to implement a social pension, i.e., a cash benefit for all elderly people. TABLE 13 simulates two approaches. Each distributes a social pension of TZS 11,000 per 
Younger, Myamba and Mdadila, WP 36, January 2016

month, ${ }^{19}$ the amount suggested in Osberg and Mboghoina (2011), to all Tanzanians aged 60 and over. The first funds this with an increase in the VAT; the second leaves it unfunded.

\section{TABLE 13 - SIMULATIONS OF SOCIAL PENSIONS}

\begin{tabular}{llll}
\hline \multirow{2}{*}{ Change in: } & & \multicolumn{2}{l}{ Simulation } \\
\hline \multirow{2}{*}{ Extreme } & Disposable Income & -0.007 & -0.007 \\
Poverty & Consumable Income & -0.008 & -0.013 \\
Headcount & Final Income & -0.008 & -0.010 \\
\hline \multirow{2}{*}{ Poverty } & Disposable Income & -0.014 & -0.014 \\
Headcount & Consumable Income & -0.005 & -0.014 \\
& Final Income & -0.006 & -0.013 \\
\hline \multirow{2}{*}{ Poverty } & Disposable Income & -0.005 & -0.005 \\
Gap & Consumable Income & -0.004 & -0.007 \\
& Final Income & -0.003 & -0.005 \\
\hline \multirow{2}{*}{ Gini } & Disposable Income & -0.004 & -0.004 \\
& Consumable Income & -0.006 & -0.004 \\
& Final Income & -0.005 & -0.003 \\
\hline & Note: Net cost, \%GDP & $0.0 \%$ & $0.5 \%$ \\
\hline
\end{tabular}

Simulation Descriptions:

(1) Social pension of TZS 11,000 per month for all people $>=60$ years, financed with increased VAT

(2) Social pension of TZS 11,000 per month for all people $>=60$ years, not financed

Note: All changes are absolute changes in the poverty and inequality measures.

While this policy would help to reduce poverty, the effects are not as large as the effects of the CCT, particularly when we insist that the transfer be funded (as we did for all simulations in TABLE 12). This is because some of the elderly (and their families) are not poor. There are other arguments in favor of social pensions, but on poverty reduction, expansion of the CCT is a more effective policy.

\section{iii. Shift Taxes from Import Duties to Personal Income Taxes}

The last striking result in Figure 2 is the extraordinary progressivity of personal income taxes, PAYE and the skills development levy. Other taxes are progressive as well, including VAT and most excises. But there are four - excises on kerosene, petrol, and tobacco, and import duties - that are either regressive (kerosene and tobacco) or neutral (petrol and import duties). This opens the possibility of using tax policy to improve the distribution of income. While there are good efficiency reasons to tax petroleum products and tobacco - they all have associated negative externalities there are no good efficiency reasons to tax imports. In fact, removing them should improve efficiency. So to examine the distributional consequences of changing tax policy, we simulate the removal of all import duties, replacing them with PAYE.

19 About US $\$ 5.50$. 
Younger, Myamba and Mdadila, WP 36, January 2016

TABLE 14 - SIMULATE A SHIFT FROM IMPORT DUTIES TO PERSONAL INCOME TAXES

\begin{tabular}{|c|c|c|c|c|}
\hline Change in: & $\begin{array}{l}\text { Extreme } \\
\text { Poverty } \\
\text { Headcount }\end{array}$ & $\begin{array}{l}\text { Poverty } \\
\text { Headcount }\end{array}$ & $\begin{array}{l}\text { Poverty } \\
\text { Gap }\end{array}$ & Gini \\
\hline Consumable Income & -0.005 & -0.007 & -0.002 & -0.004 \\
\hline Final Income & -0.003 & -0.007 & -0.001 & -0.003 \\
\hline
\end{tabular}

Note: All changes are absolute changes in the poverty and inequality measures.

Table 14 gives the results. Import duties were 1.2\% of GDP in 2011 (Table 4), so the simulation involves a large amount of money. Nevertheless, the poverty and inequality effects of this change are not as large as one might think, particularly when compared to the CCT simulations (Table 12) which involved less than half as much money. Extreme poverty declines by 0.3 to 0.5 percentage points, while poverty declines by less than one percentage point. This is despite the very high concentration coefficient of PAYE at the top end of the income distribution. The reason for this is that the difference between the concentration coefficients for import duties (0.38) and PAYE (0.94) is only a little more than half the difference between those for VAT $(0.53)$ and the CCT (-0.47). In general, all taxes, even the most regressive ones, will have positive concentration coefficients and so have incidences that are closer to each other than they are to a well-targeted transfer like the CCT. This makes it easier to affect the income distribution with such a transfer than with tax policy alone.

\section{CONCLUSIONS}

The analysis began with three questions about the redistributive effect of taxes and expenditures:

- How much redistribution and poverty reduction is being accomplished through social spending, subsidies and taxes?

- How progressive are revenue collection, subsidies, and government social spending? and

- Within the limits of fiscal prudence, what could be done to increase redistribution and poverty reduction through changes in taxation and spending?

The answer to the first question is: for inequality, quite a lot; for poverty, not much except via education and health expenditures. While it is true that many middle- and upper-income countries redistribute more than Tanzania, its 5 percentage point reduction in the Gini from activities of the fisc $^{20}$ is higher than one would expect given Tanzania's low income per capita and its relatively low initial inequality. About half of this redistribution comes from very progressive direct taxation. The rest comes from unusually progressive indirect taxation and progressive in-kind transfers in health and education. Overall, we find that the fisc moves many ex ante rich people down the income distribution, which reduces inequality (but not poverty), but does very little to move poorer people up the income distribution except for expenditures on health and education, which are large and have large positive effects on poverty reduction.

The answer to the second question requires more detail. Tanzania's direct taxation, both payroll taxes (PAYE and SDL) and presumptive taxation on formal household enterprises, are more concentrated among the rich than in any other country for which we have data. This is a result of Tanzania's small but highly-paid formal sector. Indirect taxes in Tanzania are also progressive, a somewhat unusual result. In fact, these, too, are more redistributive than any other country for

20 To be precise: the activities that we can measure in this study. 
which we have information. ${ }^{21}$ Overall, taxation in Tanzania is quite effective at redistributing resources away from richer households. We should note, however, that there are two regressive taxes in Tanzania: the excise duties on kerosene and tobacco products. While there are good efficiency reasons for these taxes - both products are associated with negative externalities - on equity grounds, government might wish to reduce them.

Results on the expenditure side of the budget are much less positive. Tanzania has only one expenditure that is well-targeted to the poor, the CCT. In 2011 (and, indeed, at the time we are writing), this remains a small program so that, despite its excellent targeting, it has very little effect on poverty and inequality. Our simulations show that Tanzania could achieve substantial reductions in poverty with even modest expansions of CCT expenditures to $0.5 \%$ of GDP.

The largest social expenditures are to provide education and health services, which is typical for developing countries. These expenditures are less well-targeted to the poor than in other countries for which we have data, though not markedly so. This is a result of lower coverage in Tanzania than other countries. A typical pattern for these services is that the middle class and sometimes the rich get them first, with the poor attaining access only as coverage expands. Tanzania is no exception. Tanzania also has the typical pattern of cheaper, basic services like primary education and health care being more equitably distributed, with more sophisticated services like higher education and hospital care being less progressive. In Tanzania, both tertiary education and vocational training are regressive, going predominantly to richer households.

Tanzania has one expenditure that is both regressive and indefensible on efficiency grounds: the subsidy for electricity. While not a huge expenditure, our simulations show that reallocating the electricity subsidy to a more progressive expenditure, the CCT, would have a substantial effect on poverty.

We have already hinted at the answers to the third question. Our top policy suggestions are:

- abandon electricity subsidies;

- expand the coverage of the CCT;

- shift the education budget away from post-secondary toward primary schooling; and

- be content with tax policy.

The rationale for the first two suggestions should be clear. For the third, we note that there is concern about the quality of primary schooling in Tanzania, especially after the large expansion in coverage that occurred in the past decade (Tanzania PER Working Group, 2011). It seems clear that primary schools would benefit from increased expenditures to reduce class sizes and guarantee adequate service delivery in more remote areas. Such spending would be more equitable than any other social spending save the CCT.

For tax policy, apart from a few minor changes such as reduced taxation of kerosene and tobacco, there are no strong equity grounds for changes. This is not to say that there are no efficiency reasons for changes in tax policy; that is not the remit of this paper. But on equity grounds, taxation in Tanzania does quite well as it is.

21 The concentration coefficient for South Africa's indirect taxes is higher than Tanzania's, but the difference between the Gini and the concentration coefficient, the Kakwani index, is greater in Tanzania. 
Younger, Myamba and Mdadila, WP 36, January 2016

\section{References}

Breceda, Karla, Jamele Rigolini, and Jaime Saavedra. 2008. "Latin America and the Social Contract: Patterns of Social Spending and Taxation," Policy Research Working Paper 4604, World Bank Latin American and Caribbean Region Poverty Department Poverty Reduction and Economic Management Division, World Bank, Washington, DC. http://go.worldbank.org/BWBRP91A50

Controller and Auditor General, 2013, Report of the Controller and Auditor General on the Financial Statements of Tanzania Electric Supply Company Limited for the Year Ended 31 December 2012. Dar es Salaam.

Development Policy Group, 2012, "Rapid Budget Analysis for Annual Review FY 2012/2013," draft.

Evans, David K. , Stephanie Hausladen, Katrina Kosec, and Natasha Reese, 2013, "Community Based Conditional Cash Transfers in Tanzania Results from a Randomized Trial," draft.

Fullerton, D. and Metcalf, G. (2002) "Tax Incidence," in Handbook of Public Economics 4, Auerbach, A. and Feldstein, M. (eds.), Elsevier Science, Amsterdam, 1787-1872.

Goñi, Edwin, J. Humberto López, and Luis Servén. 2011. "Fiscal Redistribution and Income Inequality in Latin America." World Development 39(9): 1558-1569.

Immervoll, Herwig, Horacio Levy, José Ricardo Nogueira, Cathal O’Donoghue, and Rozane Bezerra de Siqueira. 2009. "The Impact of Brazil's Tax-Benefit System on Inequality and Poverty." In Stephan Kasen, and Felicitas Nowak-Lehmann, eds., Poverty, Inequality, and Policy in Latin America, pp. 271-302. Cambridge, MA: MIT Press.

IMF, 2015, Reforming Energy Subsidies, http://www.imf.org/external/np/fad/subsidies/index.htm

Inchauste, G. and Lustig, N. ed., (forthcoming). The Distributional Impact of Fiscal Policy: Emerging evidence from developing countries. Washington D.C.: The World Bank.

López-Calva, Luis F., Nora Lustig, John Scott y Andrés Castañeda. 2014. "Gasto social, redistribución del ingreso y reducción de la pobreza en México: evolución y comparación con Argentina, Brasily Uruguay." CEQ Working Paper No. 17, Center for Inter-American Policy and Research and Department of Economics, Tulane University and Inter-American Dialogue, REVISED Lustig, Nora, ed. Forthcoming. Commitment to Equity Assessment (CEQ): Estimating the Incidence of Social Spending, Subsidies and Taxes. Tulane University and World Bank.

Lustig, Nora. 2015a. "El impacto del sistema tributario y el gasto social en la distribución del ingreso y la pobreza en América Latina: Bolivia, Brasil, Chile, Colombia, Costa Rica, Ecuador, El Salvador, Guatemala, México, Perú y Uruguay: Una aplicación del marco metodológico del proyecto Compromiso con la Equidad (CEQ)," draft.

Lustig, Nora. 2015b. "The Redistributive Impact of Government Spending on Education and Health: Evidence from 13 Developing Countries in the Commitment to Equity Project," 
Younger, Myamba and Mdadila, WP 36, January 2016

CEQ Working Paper No 30, Center for Inter- American Policy and Research and Department of Economics, Tulane University and Inter-American Dialogue.

Lustig, Nora. 2015c. "El impacto del sistema tributario y el gasto social en la distribución del ingreso y la pobreza en América Latina: Bolivia, Brasil, Chile, Colombia, Costa Rica, Ecuador, El Salvador, Guatemala, México, Perú y Uruguay,” draft.

Lustig, Nora, Ali Enami, and Rodrigo Aranda. Forthcoming, "The Analytics of Fiscal Redistribution." In Nora Lustig, and Sean Higgins, eds. Commitment to Equity Handbook: Estimating the Redistributive Impact of Fiscal Policy. Tulane University and the World Bank.

Lustig, Nora, and Sean Higgins, eds., Forthcoming. Commitment to Equity Handbook: Estimating the Redistributive Impact of Fiscal Policy. Tulane University and the World Bank.

Makawia, Suzan, Jane Macha, Mariam Ally, Josephine Borghi, 2010, "An assessment of the distribution of health service benefits in Tanzania." SHIELD Work Package 3 Report.

Ministry of Energy and Minerals, 2013, Energy Subsidy Policy: Revised Draft.

Mtei, Gemini, Suzan Makawia, Mariam Ally, August Kuwawenaruwa, Filip Meheus, and Josephine Borghi, 2012, "Who pays and who benefits from health care? An assessment of equity in health care financing and benefit distribution in Tanzania." Health Policy and Planning 27:i23i34.

Osberg, Lars and Thadeus Mboghoina, 2011, "Social Protection of the Elderly in Tanzania: Current Status and Future Possibilities"

Roland-Holst, David W., and Ferran Sancho. 1995. "Modeling Prices in a SAM Structure." The Review of Economics and Statistics. 77 (2): 361-371.

Sahn, David, and Stephen D. Younger, 1999, "Dominance Testing of Social Sector Expenditures and Taxes in Africa," IMF Working Paper No. 99/172.

Tanzania PER Working Group, 2011, United Republic of Tanzania Public Expenditure Review 2010, World Bank Report No. 64585-TZ

World Bank, 2011, “Tanzania: Poverty, Growth, and Public Transfers Options for a National Productive Safety Net Program,” Report No. AAA62-TZ.

World Bank, 2012, "Education Rapid Budget Assessment for Tanzania," draft.

World Bank, 2014, "Public Expenditure Review: Government Pension Obligations and Contingent Liabilities," draft.

Younger, Stephen D., Eric Osei-Assibey, and Felix Oppong, 2015, "Fiscal Incidence in Ghana," CEQ Working Paper No. 35, Center for Inter-American Policy and Research and Department of Economics, Tulane University and Inter-American Dialogue. 